\title{
Treatment of Basal Cell Carcinoma with Interferons Alpha-2b and Gamma in Primary Care
}

\author{
Meilyn Fernández-Martori MD MS, Iraldo Bello-Rivero MS PhD, Yaquelín Duncan-Roberts MD MS
}

\begin{abstract}
SUMMARY
INTRODUCTION Interferons have been used to treat basal cell carcinoma with positive results. Cuba's Genetic Engineering and Biotechnology Center developed HeberPAG, a combined formulation of interferons alpha- $2 \mathrm{~b}$ and gamma, for treatment of basal cell carcinoma of any size, subtype and location.
\end{abstract}

OBJECTIVE Evaluate the safety and effectiveness of using HeberPAG in primary care to treat basal cell carcinomas.

METHODS A descriptive observational study was conducted of basal cell carcinoma treated with HeberPAG. The sample comprised 21 tumors in 19 patients who met selection criteria. The dose was 3.5 million international units of antiviral activity administered by perilesional infiltration 3 times a week for 3 weeks. Clinical monitoring and laboratory testing of patients was conducted before treatment initiation and at 4, 8, 16 and 52 weeks. Variables recorded were: age, sex, skin phototype, clinical and histologic type, clinical response to treatment, changes in tumor diameters and adverse events. Four response categories were included: complete response, partial response, stable disease and progressive disease. Data were recorded in medical dossiers. Microsoft Excel and SAS were used for data management and calculation of measures of frequency, central tendency and dispersion.
RESULTS Of 19 patients studied, $63 \%$ were male, and $63 \%$ aged 61-80 years. At 16 weeks, there was an objective response in $76 \%$ of tumors (8 complete and 8 partial responses). Fewer objective responses were seen in rodent ulcer, advanced invasive and sclerosing clinical types and in the sclerodermiform histologic type. Mean sum of diameters decreased from $36.9 \mathrm{~mm}$ (SD $4.1 \mathrm{~mm}$ ) to $10.3 \mathrm{~mm}$ (SD $18.3 \mathrm{~mm}$ ). One-year recurrence was $10 \%$. The most common adverse reaction was flu-like syndrome, consisting of fever, malaise, joint pain and muscle pain.

CONCLUSIONS Basal cell carcinoma can be successfully treated in primary care settings with a combination of interferons alpha- $2 b$ and gamma administered by trained personnel. At the dose employed in this study, the formulation produces a favorable response in basal cell carcinomas of low clinical and histologic risk, and is well tolerated, with only mild side effects.

KEYWORDS Basal cell carcinoma, interferons, interferon alpha-2b, interferon gamma, primary care, Cuba

CONTRIBUTION OF THIS RESEARCH This study demonstrates the feasiblity of treating basal cell carcinoma in primary care settings with $a$ combined formulation of interferons alpha- $2 b$ and gamma, enabling management in primary care of a cancer usually treated in hospital.

\section{INTRODUCTION}

Skin cancer morbidity has tripled worldwide in the last 20 years. [1] Its incidence in Cuba is increasing, with 10,432 cases in 2016, making it the most common cancer in Cuba, surpassing both prostate cancer in men and breast cancer in women.[2] The most common type is basal cell carcinoma (BCC),[3-5] a slow-growing cutaneous neoplasm with limited malignancy and low metastatic potential.[6] In 2010-2014, the Pathological Anatomy Registry at Mario Muñoz Monroy General Teaching Hospital, in the city of Colón, Matanzas Province, Cuba, received 822 pathology reports of skin cancer, of which $68.1 \%$ were BCC.

A broad range of BCC treatment options exists, although not all are available in every medical setting. Despite great efforts, it remains a challenge to find a single treatment that is ideal for every age, comorbidity, location, histologic type, tumor size and esthetic requirement, and that assures minimum recurrence. Surgery and radiotherapy are the most effective and have low recurrence rates of $3.5 \%-5 \% .[7,8]$ Traditional nonsurgical treatment modalities are 5-fluorouracil cream, cryosurgery, curettage, electrodessication, and combinations of two or more of these.[9-14] The above methods, except for radiotherapy and cryosurgery, are used in the dermatology department of the polyclinic where this study was conducted.

The Genetic Engineering and Biotechnology Center (CIGB) in Havana, Cuba developed a new formulation of interferons alpha$2 \mathrm{~b}$ and gamma called HeberPAG, for treatment of BCC of any size, subtype and location.[15-18] It was registered with Cuba's Center for State Control of Medicines, Equipment and Medical Devices on May 23, 2008 (B-08-040-L03).[19] The objective of this study is to evaluate HeberPAG's effectiveness and safety when used in routine medical practice in a primary care setting.

\section{METHODS}

Study design and population A descriptive observational study was conducted from February 1, 2013 through February 29, 2016, of patients with histologically diagnosed BCC, treated at the provincial skin cancer clinic of the Carlos J. Finlay Polyclinic in Colón, Matanzas Province, Cuba. A dermatologist and a nurse with a degree in surgery in charge of these patients' care attended workshops on use of HeberPAG and handling of adverse events.

Included were patients aged $>18$ years, of any skin phototype, with confirmed clinical and histologic diagnosis of BCC (any clinical subtype, location, size), previously treated or not, primary or recurrent. The sample consisted of 19 participants with 21 tumors studied for one year.

Procedures and variables The study followed the Incarbacel IV clinical trial protocol,[15] which proposes a physician-selected dose of 3.5-10.5 MIU of antiviral activity. In this study, all tumors were treated with a mixture of $3.5 \mathrm{MIU}$ of interferon alpha- $2 \mathrm{~b}$ and interferon gamma. In one patient with a tumor larger than $4 \mathrm{~cm}$ (considered advanced BCC), the same dose was used, since higher doses could have compromised the patient's health. Each ampoule was diluted in one $\mathrm{mL}$ of water for injection and administered by perilesional infiltration three times a week for three weeks. Independent variables were participant age, sex, and skin phototype; and tumor clinical and histologic type. Dependent variables were clinical response to treatment 
(changes in size), laboratory results (CBC and blood chemistry), tumor diameters, and adverse events at 0, 2, 3, 4, 8, 16 and 52 weeks from treatment initiation. For laboratory variables, descriptive analyses are based on the number of tumors and not on the number of patients, since recurrence implied new laboratory determinations.

To classify results, we adopted treatment response categories based on recommendations of the Response Evaluation Criteria in Solid Tumors Group.[20] The largest and smallest tumor diameters were measured and summed. Response categories were:

- complete response (CR) — total tumor disappearance,

- partial response (PR) $-\geq 30 \%$ decrease in sum of diameters,

- progressive disease- $\geq 20 \%$ increase in sum of diameters,

- stable disease-insufficient decrease to qualify as partial response, or insufficient increase to qualify as progressive disease.

Two additional synthetic variables were created: objective response (CR plus $\mathrm{PR}$ ) and favorable response (CR or $\mathrm{PR})$.

Any reappearance of a tumor once its disappearance had been reported by clinical observation was classified as a recurrence. Tumor evolution was assessed using clinical observation, dermatoscopy or histology.

Adverse event severity was classified as: grade 1, mild; grade 2, moderate; grade 3, hospitalization required or prolonged; grade 4, severe, with risk of disability or death; and grade 5, death related to adverse event (from US National Cancer Institute's grading criteria for clinical and laboratory adverse events).[21] Anemia was assessed by measuring hematocrit (normal values in men: 0.40-0.50; in women, 0.37-0.45).[22]

Data management and analysis Data were compiled in a medical record and ledger created by CIGB. Microsoft Excel and SAS 9.0 were used for data storage and management, and to calculate statistical measures of frequency, central tendency and dispersion. Since a given patient could have more than one tumor, tumor number was used as the denominator for some analyses.

Ethics The study protocol was reviewed and approved by the ethics committees of the Dr Carlos J. Finlay Polyclinic and Medical University of Matanzas. The study complied with the principles of the Helsinki Declaration.[23] Written, informed consent was obtained from study participants, and study documents were stored on site at the polyclinic, along with evaluations by clinical trial monitors and sponsors.

\section{RESULTS}

Of the 19 patients studied, $12(63 \%)$ were male, and $12(63 \%)$ were aged $61-80$ years. All had white skin color, phototypes II or III. There were 21 tumors in all because 2 patients had second tumors (Table 1). Tumors were located on the head, face and neck in $16(76 \%)$. Among clinical types, 11 were nodular $(52 \%)$; histologically, 10 (48\%) were solid tumors (Table 1).

Figure 1 shows the distribution of mean sum of diameters in patients treated with HeberPAG, and its pattern over time. When calculating means, one outlier tumor was omitted. The minimum tumor sum
Table 1: Characteristics of patient BCCs treated with HeberPAG at Carlos Finlay Polyclinic, Colón, Matanzas, Cuba, 2013-2016

\begin{tabular}{l|r}
\hline Variable & $\mathbf{n}(\%)$ \\
\hline Sex & \\
\hline Female & $7(37)$ \\
Male & $12(63)$ \\
\hline Age (years) & \\
$<40$ & \\
$41-60$ & $1(5)$ \\
$61-80$ & $3(16)$ \\
$>80$ & $12(63)$ \\
Range & $3(16)$ \\
Mean (SD) & $34-96$ \\
& $69.1(15.4)$ \\
Skin phototype & \\
II & \\
III & $9(47)$ \\
\hline Tumor clinical type ${ }^{\mathrm{b}}$ & $10(53)$ \\
Nodular & \\
Multiple superficial & $11(52)$ \\
Sclerosing & $3(14)$ \\
Rodent ulcer & $2(10)$ \\
Advanced invasive & $4(19)$ \\
\hline Tumor histologic type ${ }^{\mathrm{b}}$ & $1(5)$ \\
Solid & \\
Superficial & $10(48)$ \\
Sclerodermiform & $2(10)$ \\
Unspecified & $5(24)$ \\
\hline & $4(19)$ \\
\hline
\end{tabular}

$a_{n}=19 \quad{ }^{b} n=21 \quad$ BCC: basal cell carcinoma

Figure 1: Changes in BCC size after treatment with HeberPAG $(n=20)^{*}$

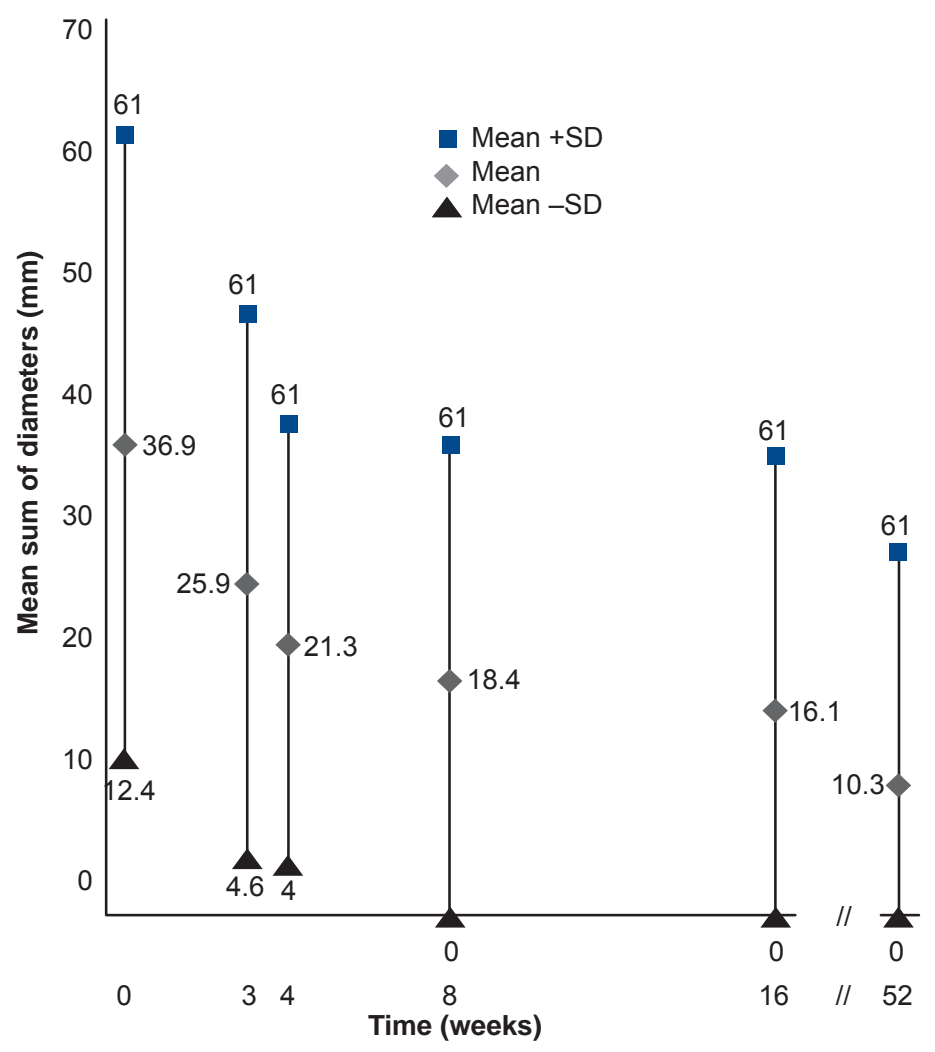

${ }^{*}$ One outlier omitted

BCC: basal cell carcinoma 
Table 2: BCC clinical response to HeberPAG at weeks 16 and 52 ( $n=21)$

\begin{tabular}{|l|r|r|}
\hline Response & $\begin{array}{r}\text { Week 16 } \\
\text { n (\%) }\end{array}$ & $\begin{array}{r}\text { Week 52 } \\
\text { n (\%) }\end{array}$ \\
\hline Objective (CR+PR) & $16(76)$ & $14(67)$ \\
\hline Complete (CR) & $8(38)$ & $11(52)$ \\
\hline Partial (PR) & $8(38)$ & $3(14)$ \\
\hline Stable disease & $4(19)$ & $4(19)$ \\
\hline Progressive disease & $1(5)$ & $1(5)$ \\
Recurrence within one year & - & $2(10)$
\end{tabular}

BCC: basal cell carcinoma

of diameters at treatment initiation was $6 \mathrm{~mm}$; maximum was 75 $\mathrm{mm}$ (the outlier measured $190 \mathrm{~mm}$ ). A decrease in mean sum of diameters was observed, from $36.9 \mathrm{~mm}$ (SD 24.1) at treatment initiation to $10.3 \mathrm{~mm}$ (SD 8.3) at week 52. Tumors disappeared in four patients, beginning in week 8 .

Table 2 shows tumor clinical response at weeks 16 and 52 after treatment initiation. Of 11 complete responses, 7 (64\%) were treated with HeberPAG alone, and $4(36 \%)$ also underwent surgery. Tumors classified as stable and progressive at week 16 remained in their respective categories at week 52. Two tumors $(10 \%)$ recurred after complete clinical disappearance. One female patient with partial response at week 16 achieved complete response weeks later, and maintained that response at week 52 . For patients without complete responses, we proposed a second round of the product or combining it with surgery. Four patients with partial responses decided to complete treatment with surgery. These patients were assessed one year later and had no recurrences; these were considered complete responses. The tumor classified as progressive at week 16 remained in progression at the one-year mark, and the patient died some time later. This was a recurrent, previously treated solid tumor that had first appeared over 10 years earlier; it was classified clinically as advanced invasive and had the largest sum of diameters (190 mm).

Figure 2 shows clinical response to treatment by clinical type. Nodular tumors had the greatest number of objective responses.

Figure 2: BCC response to HeberPAG at week 16, by clinical type $(n=21)$

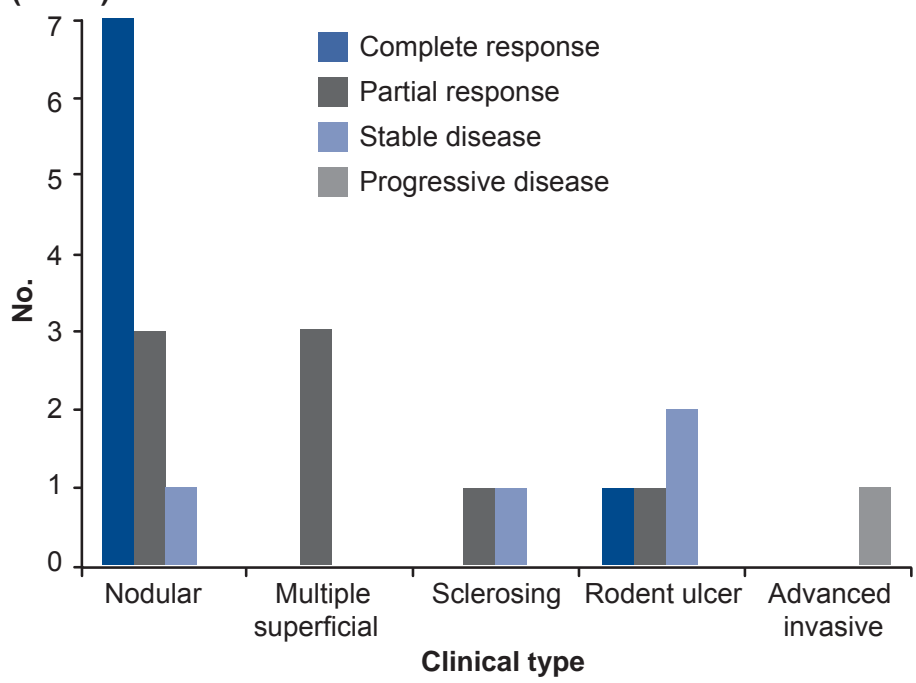

BCC: basal cell carcinoma
Figure 3: BCC response to HeberPAG at week 16, by histologic type $(\mathrm{n}=17)^{\star}$

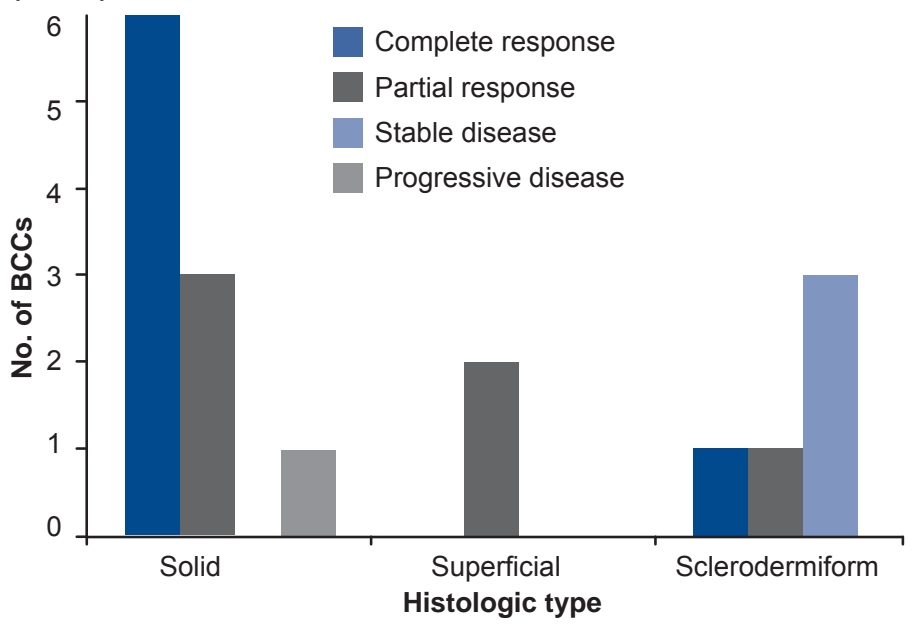

*Histologic type unspecified for 4 tumors BCC: basal cell carcinoma

Multiple superficial BCCs responded favorably, and all tumors of this type showed partial response. Sclerosing and rodent ulcer tumors showed less response, and an advanced invasive BCC (the outlier) did not respond.

Figure 3 shows clinical response to treatment by histologic type. Solid and superficial BCCs showed mostly favorable responses. One solid tumor showed progression in a patient who had risk factors for poor prognosis. The sclerodermiform subtype remained stable in three of five tumors.

Figure 4: Adverse reactions to HeberPAG $(n=21)^{*}$

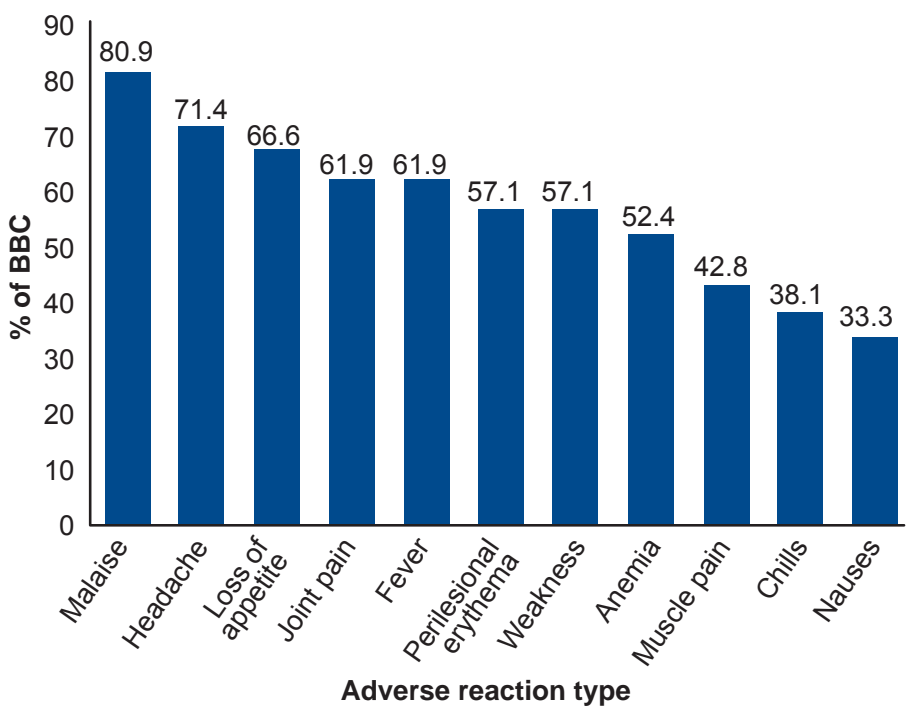

*21 tumors in 19 patients

Note: In addition, all treated patients had pain in the infiltration area.

Figure 4 shows adverse reactions to HeberPAG. Blood values were checked at each followup visit, up to week 52. We observed below-normal hemoglobin figures in $52 \%$ of patients at week 4 , and in $43 \%$ at week 16 . Most adverse events were fleeting, appearing on day of treatment and improving within 24 hours. Once loss of appetite appeared, in most cases it persisted until one to two weeks after the last dose. All patients reported 
localized pain during infiltration. Muscle pain, chills and nausea were reported in fewer than half of patients, who were advised to take 2 dipyrone tablets and 1 diphenhydramine tablet every 12 hours while symptoms persisted.

Below-normal hematocrit values were detected in 7 patients before treatment began, with minimum values of 0.36 in women and 0.35 in men; these were cases of mild anemia, not cause for exclusion from treatment. The patient with hematocrit 0.35 was also included and received customary oral treatment with ferrous fumarate and vitamin C. After week 4 of treatment, mild anemia was found in 11 of 19 patients; in 2 patients, hematocrit could not be measured at week 4 . Of the 11 patients with mild anemia, 6 had below-normal levels before infiltration. After treatment, hematocrit values decreased in 5 patients whose initial values were normal. The lowest hematocrit measured at week 4 was 0.30 , in the same patient whose hematocrit was 0.35 before treatment. At week 16, 9 patients had anemia, 8 of them mild cases, with a minimum hematocrit of 0.31 , while 1 had moderate anemia (hematocrit 0.25). Of these 9 patients, 4 had low levels before treatment, and 5 of the 11 with low levels at week 4 returned to normal values at week 16 . Of the 19 patients, 7 maintained normal hematocrit levels during the followup period, with 2 patients assessed twice (hematocrit testing was repeated in 2 patients when their second tumor was treated), for a total of 21 determinations.

\section{DISCUSSION}

Local treatment with interferon alpha-2b, an immune response modifier, has been used for low-risk BCCs. It is the most frequently used intralesionally acting molecule, with an optimal dose of $1.5 \mathrm{MIU}, 3$ times a week for 3 weeks, showing response in $80 \%-83 \%$ of small superficial and nodular BCCs. [24] It is effective in treatment of BCC and squamous cell carcinoma, with a response range of $60 \%-100 \%$ and low recurrence $(4 \%)$, although in our references, duration of response was not specified.[18,25] Feinsilber obtained $75 \%$ effective response in BCC using a $3 \mathrm{MIU}$ dose of interferon alpha-2b for BCCs measuring $<2 \mathrm{~cm}$ and $5 \mathrm{MIU}$ for larger tumors.[26] Since then, others have studied interferon as a BCC treatment option. $[26,27]$

In Cuba, use of interferon alpha-2b in BCC at a dose of 1.5 MIU 3 times a week for 3 weeks was examined in a quasiexperimental study conducted in 2012-2013 at Amalia Simoni Hospital in Camagüey province, with $70 \%$ complete response,[28] comparable to what we observed at 52 weeks.

The first results using the synergistic interferon formulation for advanced, recurrent and treatment-resistant basal cell and squamous cell carcinomas in Cuba at dosages of 3-21 MIU were published in 2009 by the National Oncology and Radiobiology Institute (INOR), Havana. Results were encouraging, with an objective response of $86.7 \%(46.7 \%$ complete and $40 \%$ partial). In patients whose tumors had infiltrated bone or other areas beyond reach of a needle, HeberPAG treatment was combined with chemotherapy.[16] These results had a clear impact, showing HeberPAG to be an excellent new adjunct treatment for BCC, with an average sustained clinical response of 38 months.[18]
HeberPAG was used in 2011-2012 in two primary care settings in rural Mayabeque Province: the Noelio Capote Polyclinic in Jaruco and the Luis Li Trejent Polyclinic in Güines.[18,25] Results from these sites are part of a retrospective study that also included patients treated at two Havana hospitals: INOR and Hermanos Ameijeiras Clinical-Surgical Teaching Hospital. All these patients had received a clinical and histologic diagnosis of periocular nonmelanoma skin tumor (BCC or squamous cell carcinoma). The study included several clinical trials administering doses from 0.875 to 27 MIU 3 times a week for 3 weeks.[18,25]

The InCarbacel II trial, a comparative clinical trial whose objective was to assess the safety and efficacy of a 1.75MIU dose of HeberPAG versus interferon alpha-2b, obtained 42.1\% CR with HeberPAG and 33.3\% CR with interferon alpha-2b. Patients treated with HeberPAG showed CR one month earlier than patients treated with interferon alpha- $2 b$ alone.[15] CR was maintained for at least one year in all patients.[18] These results are similar to those of our study, which used the same treatment frequency but a higher dose.

In a patient with nodular periocular BCC diagnosed 3 years earlier, it was reported that clinical signs of the tumor disappeared after 12 weeks of treatment with HeberPAG (3.5 MIU). Dermatoscopy detected a $1-\mathrm{mm}$ remnant that was surgically excised. Investigators confirmed that HeberPAG is useful as a nonsurgical option for treatment of periocular tumors. In their opinion, this experience revealed a synergy that had not been previously observed, at a higher dose of interferon alpha-2b than proposed in the literature.[17] Rueda states that the optimal dose for treatment of superficial and small nodular BCCs is $1.5 \mathrm{MIU}$, with good cosmetic and therapeutic response of $80 \%-83 \%$,[24] although the authors of the case described above conclude that a higher dose may produce a better, faster and longer-lasting response.[17]

The InCarbacel III study, a dose-setting clinical trial of HeberPAG, reported objective responses of $93 \%$, with $60 \%$ CR for the 7-MIU dose arm, and $85 \%$ CR for the 10.5-MIU dose arm. Considering both trials, which were included in the same publication, the authors concluded that HeberPAG is useful in treating $\mathrm{BCC}$, and that the dose eliciting the highest CR is $10.5 \mathrm{MIU}$.[15] These results of dose-setting studies were published after the product registration that guided our study, which prescribes a $3.5-\mathrm{MIU}$ dose for tumors measuring $\leq 4$ $\mathrm{cm}$ and a 10.5-MIU dose for tumors measuring $>4 \mathrm{~cm} .[15,18]$ In our study, we did not use a higher dose for the BCC that measured $>4 \mathrm{~cm}$, to avoid adverse reactions in that patient. At the 3.5-MIU dose, responses we obtained were similar to those observed in the InCarbacel II and III clinical trials.[18] Better responses might have been obtained had the sample been more homogeneous in tumor size and other risk factors (we treated a tumor with total sum of diameters of $190 \mathrm{~mm}$ at the same dose as tumors with total sums of diameters of 6 $\mathrm{mm}$ ). This aspect should be addressed in future studies.

The largest tumor assessed in this study demonstrates the importance of dosage. Every characteristic of the tumor indicated that it was a high-risk BCC. Its histologic type was solid, its clinical type advanced invasive (such tumors are 
known to be difficult to treat).[24] In addition to having first appeared 10 years earlier and recurring after radiotherapy, it progressed after treatment, and the patient died two years later. This type of $\mathrm{BCC}$ requires high doses of HeberPAG (10.5 MIU) in combination with an oral antineoplastic agent. It is important to assess all risk factors that may influence response to treatment. High-risk BCCs require multiple rounds of HeberPAG or larger doses, as high as $21 \mathrm{MIU} .[16,18]$

Various clinical factors have been identified in risk of recurrence. Tumor-related factors include size, location, time since appearance, clinical type, histopathologic factors (such as perineural invasion, reduced surgical margins and histologic pattern). Patient-related factors include age, sex, skin phototype, immune status and history of sun exposure). $[6,10,29]$

In our study, the two patients with recurrences had been surgically treated more than twice; their cases involved recurrent $B C C$ in high-risk locations (eyelid and nose), one with sclerodermiform histology and the other a mixed BCC with areas of squamous cell carcinoma.

These results suggest that this type of $B C C$ requires HeberPAG doses of $>3.5 \mathrm{MIU}$, and when choosing this dose, a risk factor assessment must be performed. However, one clinical trial on the product concluded that in patients with locally advanced tumors, doses of $\geq 10.5$ MIU should be used, which increase the number of objective responses, with a mean response duration of 38 months; only one patient with a CR relapsed, after 5 years of followup. These authors state that the risk of local recurrence is individual, and suggest that the low recurrence rate in patients treated with HeberPAG may be due to the potent antitumor effect of the new formulation of interferons,[16] which has synergistic antiproliferative properties.[18] Recurrence after Mohs surgery (a treatment of choice) is $6.5 \%$ after 5 years of followup, but due to its high cost, it is reserved for recurrent BCCs or high-risk facial BCCs. Vismodegib, approved for treatment of locally advanced BCCs, has a mean response duration of 7.6-9.5 months.[18,25]

It is important to assess each BCC clinical and histologic subtype to estimate its specific risk. In our study, nodular BCCs showed the best treatment response. The three superficial BCCs, which had lateral but shallow subclinical extension, showed partial response. In ulcerative or sclerosing BCCs (which have a poor prognosis and wide, deep subclinical extension) and advanced invasive BCC (especially aggressive tumors with rapid growth and invasion of deep layers) diameters showed little change, and more than half showed no favorable response. Similar patterns, dependent on the clinical nature of the tumor, have been observed in other studies.[24,30]

Nodular BCC has a good prognosis because it is the most circumscribed of all BCCs. Superficial BCCs do not invade deeper layers, but can have major subclinical lateral extension, although to a lesser extent than sclerosing BCCs. Micronodular, sclerosing and trabecular BCCs have an infiltrating growth pattern with subclinical lateral or deep extension. They are not circumscribed, and therefore have a poor prognosis.[24]
Studies published on the use of HeberPAG have not reported treatment response by clinical and histologic subtype, but there is evidence from studies conducted in Cuba using interferon alpha- $2 b$ on clinical variants. In subtypes with low clinical risk (superficial, nodular and pigmented), $70 \%$ showed objective responses (CR 60\%, PR 10\%), while in high-risk subtypes (ulcerative, infiltrative and sclerosing) only $10 \%$ showed CR.[28] These responses are similar in the histologic subtypes we have mentioned, which show the same behavior and level of aggression when assessed by clinical and histologic type.

Intralesional treatment has the advantage of achieving high local drug concentrations, with less drug entering the bloodstream than with systemic (oral or IV) therapy,[30-34] and fewer serious adverse events.[35] All adverse events reported in this study were mild, with no need to suspend treatment or lower the dose, consistent with descriptions of event type, severity and cause reported elsewhere.[16,25,28] Consistent with other authors' findings, our results indicate that the safety profile of HeberPAG is similar to that of other interferon formulations, and so can be employed in similar treatment plans and combined treatment regimens.[7,16,36,37] Premedication with dipyrone and diphenhydramine was also used in early studies of the product.[25]

In $\mathrm{BCC}$, interferon alpha-2b induces an antitumor immune response that stimulates Th1 lymphocyte production and promotes formation of a peritumoral inflammatory infiltrate, mostly CD4 ${ }^{+} \mathrm{T}$ cells around tumor nests and, to a lesser extent, $\mathrm{CD}^{+} \mathrm{T}$ cells and some killer cells.[37] Interferon increases cell differentiation, has an antiproliferative effect, intensifies antitumor antigen expression, increases ICAM-1 expression, increases natural killer cell and macrophage activity, increases production of IL-1 and IL-2, lowers BCC production of IL-10, and induces tumor cell apoptosis, mediated by increased Fas receptor expression in BCC cells.[38] The combination of interferon alpha-2b and interferon gamma is intrinsically costimulating because it contains the main representatives of a Th1 response.[16,18,39] This mechanism explains why perilesional edema and erythema occur after the first infiltration and continue until the last dose; both reactions are indicators of the drug's effectiveness, and are not cause for treatment suspension.

Vismodegib and sonidegib, two of the systemic medications for advanced metastatic BCC, were approved by the US FDA in 2012 and 2015, respectively.[40,41] Both these drugs and HeberPAG are effective in treating advanced BCC; however, HeberPAG is safer because it has fewer and milder adverse effects.[16,17] Severe reactions have been reported for the two systemic medications (muscle spasms, hepatotoxicity, alopecia, weight loss, fatigue and elevated creatinine).[41,42] Both systemic medications are used until tumor regression is achieved, and treatment is suspended if progression or severe toxicity is observed. Mean treatment duration for vismodegib is 7.6 months[18,41,43] and 13.9 to 18.1 months for sonidegib. $[33,40,42]$

Until recently, interferons alpha-2b and gamma were found in separate formulations. Their combined formulation is an innovative alternative. When interferon alpha-2b is given alone, 
it causes more serious adverse reactions than when combined with interferon gamma.[18]

Coadministration also improves the clinical effect of each interferon compared to separate administration, and the combined formulation has longer systemic retention and better pharmacokinetics and pharmacodynamics than interferon alpha-2b alone.[16,18,39,44]

HeberPAG is an option for tumors of any size. For large tumors, it needs to be combined with other topical or surgical treatments. It is also used for locations where surgery may compromise esthetics and function, for tumor reduction until surgical removal is possible, after surgery in patients with poor hemostasis (whether from anticoagulants or other causes) and for treatment of patients who refuse surgery.[16-18]
Small sample size was a limitation of this study. Nevertheless, it demonstrated successful treatment with HeberPAG in a primary care setting, with locally available resources and polyclinic staff trained to administer HeberPAG.

\section{CONCLUSIONS}

Basal cell carcinoma can be successfully treated in primary care settings using a synergistic combination of interferons alpha- $2 \mathrm{~b}$ and gamma administered by trained personnel. At the dose employed in this study, the formulation produces a favorable response in BCCs of low clinical and histologic risk, and is well tolerated, with only mild side effects.

\section{ACKNOWLEDGMENTS}

Our thanks to nurses Félix R. Marrero Ojito and Idania Pérez Peñalver of the Carlos J. Finlay Polyclinic in Colón, Matanzas Province, Cuba. $-1 /$ -

\section{REFERENCES}

1. Aceituno $P$, Buendía A, Arias $S$, Serrano $S$ Evolución de la incidencia del cáncer de piel en el período 1978-2002. Actas Dermosifiliogr [Internet]. 2010 [cited 2017 Dec 12];101(1):3946. Available from: https://www.ncbi.nlm.nih.gov/ pubmed/20109391. Spanish.

2. National Health Statistics and Medical Records Division (CU). Anuario Estadístico de Salud 2016 [Internet]. Havana: Ministry of Public Health (CU); 2017 [cited 2017 Apr 10]. 206 p. Available from: http://files.sld.cu/dne/files/2017/05/Anuario Esta d\%C3\%ADstico_de_Salud_e_2016_edici\% C3\%B3n_2017.pdf. Spanish.

3. Viñas García M, Algozaín Acosta Y, Álvarez Campos L, Quintana Díaz JC. Comportamiento del carcinoma basocelular facial en Artemisa durante la última década. Rev Cubana Estomatol [Internet]. 2011 [cited 2016 Jan 31];48(2). Available from: http://www.bvs.sld.cu/revistas/ est/vol48_2_11/est04211.htm. Spanish.

4. Chinem VP, Miot HA. Epidemiology of basal cell carcinoma. An Bras Dermatol [Internet]. 2011 [cited 2012 Aug 1];86(2):292-305. Available from: www.scielo.br/pdf/abd/v86n2/en_v86n2a13.pdf Spanish.

5. Kyrgidis A, Vahtsevanos K, Tzellos TG, Xirou $\mathrm{P}$, Kitikidou $\mathrm{K}$, Antoniades $\mathrm{K}$, et al. Clinical, histological and demographic predictors for recurrence and second primary tumours of head and neck basal cell carcinoma. A 1062 patientcohort study from a tertiary cancer referral hospital. Eur J Dermatol [Internet]. 2010 MayJun [cited 2016 Jan 31];20(3):276-82. Available from: http://www.john-libbey-eurotext.fr/medline .md?doi=10.1684/ejd.2010.0903

6. Negrín Díaz ML. Carcinoma basocelular. Dermatol Venezolana [Internet]. 2008 [cited 2016 Jan 31];46(1):4-16. Available from: http://revista .svderma.org/index.php/ojs/article/view/75. Spanish.

7. Chren MM, Torres JS, Stuart SE, Bertenthal D, Labrador RJ, Boscardin WJ. Recurrence after treatment of nonmelanoma skin cancer: a prospective cohort study. Arch Dermatol [Internet]. 2011 May [cited 2016 Feb 10];147(5):540-6. Available from: https://www .ncbi.nlm.nih.gov/pmc/articles/pmid/21576572/

8. Chren MM, Linos E, Torres JS, Stuart SE, Parvataneni R, Boscardin WJ. Tumor recurrence 5 years after treatment of cutaneous basal cell carcinoma and squamous cell carcinoma. J Investigative Dermatol [Internet]. 2013 May [cited 2016 Feb 10];133(5):1188-96. Available from: https://www.ncbi.nlm.nih.gov/pmc/articles/ PMC3711403/
9. Conejo-Mir J, Conejo-Mir L. Nuevas dianas terapéuticas en carcinomas basocelulares. Med Cutan Iber Lat Am [Internet]. 2010 [cited 2015 Nov 11];38(3):105-8. Available from: www.medigraphic.com/pdfs/cutanea/mc-2010/ mc103a.pdf. Spanish.

10. Aguayo-Leiva IR, Ríos-Buceta L, JaénOlasolo P. Tratamiento quirúrgico vs. no quirúrgico en el carcinoma basocelular. Actas Dermosifiliogr [Internet]. 2010 Oct [cited 2016 Jan 31];101(8):683-92. Available from: http:// www.actasdermo.org/es/tratamiento-quirurgico -vs-no-quirurgico/articulo/S0001731010002796/. Spanish.

11. Bath-Hextall FJ, Perkins W, Bong J, Williams HC Interventions for basal cell carcinoma of the skin. Cochrane Database Syst Rev [Internet]. 2007 Jan 24 [cited 2013 Jul 19];(1):CD003412. Available from: https://dx.doi.org/10.1002/14651858.CD00 3412.pub2

12. Good LM, Miller MD, High WA. Intralesional agents in the management of cutaneous malignancy: a review. J Am Acad Dermatol [Internet]. 2011 Feb [cited 2017 Apr 23];64(2):413-22. Available from: https://linkinghub.elsevier.com/retrieve/pii// S0190-9622(09)02283-X

13. Silva Siwady JG. Principios prácticos de criocirugía. Dermatol Rev Mex [Internet]. 2013 Jan-Feb [cited 2017 Jan 25];57(1):73-7. Available from: http://www.medigraphic.com/ pdfs/derrevmex/rmd-2013/rmd131m.pdf. Spanish.

14. Gaitanis G, Alexopoulos E, Bassukas ID Cryosurgery is more effective in the treatment of primary, non-superficial basal cell carcinomas when applied during and not prior to a five week imiquimod course: a randomized, prospective open-label study. Eur J Dermatol [Internet]. 2011 [cited 2013 Jul 19];21(6):952-8. Available from: http://www.ncbi.nlm.nih.gov/pubmed/21926038

15. National Clinical Trials Coordination Center (CU). Registro Público Cubano de Ensayos Clínicos [Internet]. Havana: National Clinical Trials Coordination Center (CU); c2017. Combinación de los interferones en los carcinomas basocelulares (Estudio InCarbacel IV); [cited 2017 Jan 25]. Available from: http://registroclinico .sld.cu/ensayos/RPCEC00000164-Sp. Spanish.

16. Anasagasti-Angulo L, García-Vega Y, BarcelonaPérez S, López-Saura P, Bello-Rivero I. Treatment of advanced, recurrent, resistant to previous treatments basal and squamous cell skin carcinomas with a synergistic formulation of interferons. Open, prospective study. BMC Cancer [Internet]. 2009 Jul 30 [cited 2017 Apr
23];9:262. Available from: https://www.ncbi.nlm .nih.gov/pmc/articles/PMC2724551/

17. Jiménez Barbán $Y$, Vega Pupo $C$, Vila Pinillo $\mathrm{D}$, Fernández Ychaso G, Arias Núñez V, Bello Rivero I. Uso de HeberPAG en carcinoma basocelular periocular. Rev Cubana Oftalmol [Internet]. 2014 Jul-Sep [cited 2017 Oct 6];27(3):482-9. Available from: http://scielo.sld .cu/scielo.php?script=sci_arttext\&pid=S0864-21 762014000300014\&Ing=es. Spanish.

18. Bello-Rivero I, García-Vega Y, Valenzuela-Silva C, Bello-Álvarez C, Vázquez-Blomquist D, LópezSaura P. Development of a new formulation of interferons (HEBERPAG) for BCC treatment. J Cancer Res Ther [Internet]. 2013 Dec [cited 2017 Oct 2];1(10):235-43. Available from: http:// www.nobleresearch.org/Doi/10.14312/2052-49 94.2013-36

19. Center for State Control of Medicines, Equipment and Medical Devices (CU) [Internet]. Nationa Drug Formulary. Havana: Center for State Control of Medicines, Equipment and Medical Devices (CU); c2017 [cited 2017 Jan 27]. Available from: http://fnmedicamentos.sld.cu/ index.php?P=aplicacionAndroid. Spanish.

20. Eisenhauer EA, Therassse $P$, Bogaerts $J$ Schwartz LH, Sargent D, Ford R, et al. New response evaluative criteria in solid tumors. Revised RECIST guideline (versión 1.1). Eur J Cancer. 2009 Jan [cited 2017 Oct 6];45(2):22847. Available from: http://www.bioclinica.com/ assets/Uploads/recist_response-evaluation.pdf

21. U.S. Department of Health and Human Resources. A Common Terminology Criteria for Adverse Events (CTCAE), Version 4.0 ( $v$ 4.03: June 14, 2010) [Internet]. Washington, D.C.: U.S. Department of Health and Human Resources; 2009 May 28 [cited 2017 Apr 23]. 194 p. Available from: https://evs.nci.nih gov/ftp1/CTCAE/CTCAE 4.03_2010-06-14 QuickReference_5x7.pdf

22. Red Cubana de Patología Clínica [Internet]. Havana: National Medical Sciences Information Center (CU); c2017. Intervalos de Referencia, Hematología y Hemostasia Adultos; 2017 [cited 2017 Dec 18]. Available from: http://www.sld.cu/uvs/ patologiaclinica/temas. php?idv=14631. Spanish.

23. World Medical Association. Declaración de Helsinki de la AMM - Principios éticos para las investigaciones médicas en seres humanos [Internet]. 2013 [cited 2017 Apr 23]. Available from: http://www.unav.es/cdb/ammhelsinki2.html. Spanish.

24. Rueda X, Acosta de Hart A, Aristizabal L, Fierro E. Guías de práctica clínica para 
el tratamiento del carcinoma basocelular. Rev Asoc Col Dermatol [Internet]. 2008 Jun [cited 2016 Jan 31];16(Suppl):102-15. Available from: http://www.imbiomed.com/1/1/ articulos.php? method=showDetail\&id articu lo=51979\&id_seccion=3262\&id_ejemplar $=5264$ \&id_revista=196. Spanish.

25. García-Vega Y, Anasagasti-Angulo L,ValenzuelaSilva C, Navarro-Mestre M, Maribeth-Ordoñez $S$, Acosta-Medina D, et al. Retrospective study of periocular non melanoma skin cancer treated with the combination of IFN alfha2b and gamma (HeberPAG). J Clin Exp Ophthalmol [Internet]. 2015 Sep 26 [cited 2016 Jan 31];6(5):478. Available from: http://dx.doi.org/10.4172/2155-95 70.1000478

26. Feinsilber DG, Kogan NN, Schroh RG, Veira R. Interferón: tratamiento alternativo con infiltración intralesional en el carcinoma basocelular. Arch Argent Dermatol [Internet]. 2001 Mar-Apr [cited 2016 Feb 2];51(2):55-65. Available from: http:// pesquisa.bvsalud.org/portal/resource/es/lil -288889. Spanish.

27. Petrunin DD, Okovityı̆ SV, Kostalevskaia AV, Suchkov SV. [Approaches to immunotherapy in different immunophenotypes of cutaneous basal cell carcinoma].Vopr Onkol [Internet]. 2012 [cited 2016 Jan 31];58(3):406-12, 415. Available from: http://www.ncbi.nlm.nih.gov/pubmed/22888660. Russian.

28. Ballester Caballero Y, Rodríguez JL, Campollo I, Cabrera M, Rojas A. Tratamiento con interferón alfa-2B recombinante en el carcinoma basocelular. Revista Electrónica de Portales Medicos.com [Internet]. 2015 [cited 2016 Feb 10];10(22):944. Available from: https://www .revista-portalesmedicos.com/revista-medica/ tratamiento-con-interferon-alfa-carcinoma-baso celular/. Spanish.

29. Ocanha JP, Dias JT, Miot HA, Stolf HO, Marques ME, Abbade LP. Relapses and recurrences of basal cell face carcinomas. An Bras Dermatol [Internet]. 2011 Mar-Apr [cited 2017 Apr 23];86(2):386-8. Available from: http://www.scielo.br/scielo.php?script=sci _arttext\&pid=S0365-05962011000200032\&lng= en\&nrm=iso\&tlng=en. English, Portuguese.

30. Mosterd K, Arist AH, Thissen MR, KellenersSmeets NW. Histology-based treatment of basal cell carcinoma. Acta Derm Venereol [Internet]. 2009 [cited 2017 Apr 23];89(5):454-8. Available from: https://www.medicaljournals.se/acta/con tent/abstract/10.2340/00015555-0710

31. Danial $C$, Sarin $K Y$, Oro AE, Chang AL. An investigator-initiated open-label trial of sonidegib in advanced basal cell carcinoma patients resistant to Vismodegib. Clin Cancer Res [Internet]. 2016 Mar 15 [cited 2017 Apr 23];22(6):1325-9. Available from: http:// clincancerres.aacrjournals.org/cgi/pmidlookup?vi ew=long\&pmid $=26546616$
32. Axelson M, Liu K, Jiang X, He K, Wang J, Zhao $\mathrm{H}$, et al. U.S. Food and Drug Administration approval: Vismodegib for recurrent, locally advanced, or metastatic basal cell carcinoma. Clin Cancer Res [Internet]. 2013 May 1 [cited 2017 Apr 23];19(9):2289-93. Available from: http://clincancerres.aacrjournals.org/cgi/pmidloo kup? view=long \&pmid=23515405

33. Burness CB, Scott LJ. Sonidegib: a review in locally advanced basal cell carcinoma. Target Oncol [Internet]. 2016 Apr [cited 2017 Apr 23];11(2):239-46. Available from: https://dx.doi .org/10.1007/s11523-016-0418-9

34. Keserü M, Green S, Dulz S. [Vismodegib Therapy for Periocular Basal Cell Carcinoma]. Klin Monbl Augenheilkd [Internet]. 2017 Jan [cited 2017 Apr 23];234(1):64-9. Available from: http://www.thieme-connect.com/DOI/DOI?10 .1055/s-0042-121606. German.

35. Allevato MA. Fármacos antineoplásicos cutáneos. Act Terap Dermatol [Internet]. 2008 [cited 2016 Jan 31];31:78-91. Available from: http://www.atdermae.com/pdfs/atd_31_02_02 .pdf. Spanish.

36. Silverman MK, Kopf AW, Grin CM, Bart RS, Levenstein MJ. Recurrence rates of treated basal cell carcinomas. Part 1: Overview. J Dermatol Surg Oncol [Internet].1991 Sep [cited 2016 Jan 31];17(9):713-8. Available from: https://www .ncbi.nlm.nih.gov/pubmed/?term=Recurrence+ra tes+of+treated+basal+cell+carcinomas.+Part+1 $\% 3 \mathrm{~A}+$ Overview

37. Vidal D, Matías-Guiu X, Alomar A. Open study of the efficacy and mechanism of action of topical imiquimod in basal cell carcinoma. Clin Exp Dermatol [Internet]. 2004 Sep [cited 2017 Apr 23];29(5):518-25. Available from: http:// onlinelibrary. wiley.com/resolve/openurl?genre=a rticle\&sid=nlm:pubmed\&issn=0307-6938\&date= 2004 \& volume $=29$ \&issue $=5 \&$ spage $=518$

38. Dai M, Wei H, Yip YY, Feng Q, He K, Popov $\mathrm{V}$, et al. Long-lasting complete regression of established mouse tumors by counteracting Th2 inflammation. J Immunother [Internet]. 2013 May [cited 2017 Apr 23];36(4):248-57. Available from: https://www.ncbi.nlm.nih.gov/pmc/articles/ pmid/23603859/

39. García-Vega Y, García-García I, CollazoCaballero SE, Santely-Pravia EE, Cruz-Ramírez $A$, Tuero-Iglesias AD, et al. Pharmacokinetic and pharmacodynamic characterization of a new formulation containing synergistic proportions of interferons alpha-2b and gamma (HeberPAG) in patients with mycosis fungoides: an open-label trial. BMC Pharmacol Toxicol [Internet]. 2012 Dec 28 [cited 2017 Apr 23];13:20. Available from: https://www.ncbi.nlm.nih.gov/pmc/articles/ pmid/23272809/

40. Jacobsen AA, Aldahan AS, Hughes OB, Shah VV, Strasswimmer J. Hedgehog pathway inhibitor therapy for locally advanced and metastatic basal cell carcinoma: a systematic review and pooled analysis of interventional studies. JAMA Dermatol [Internet]. 2016 Jul 1 [cited 2017 Apr 23];152(7):816-24. Available from: http:// jamanetwork.com/journals/jamadermatology/ fullarticle/2516221

41. Ruiz-Salas V, Alegre $M$, López-Ferrer A, Garcés JR. Vismodegib: a review. Actas Dermosifiliogr [Internet]. 2014 Oct [cited 2017 Oct 2];105(8):744-51. Available from: http://www .elsevier.es/en/linksolver/pdf/pii/S0001-7310 (13)00371-2. English, Spanish.

42. Kish T, Corry L. Sonidegib (Odomzo) for the systemic treatment of aults with recurrent, locally advanced basal cell skin cancer. P T [Internet]. 2016 May [cited 2017 Oct 2];41(5):322-5. Available from: https://www.ncbi.nlm.nih.gov/ pubmed/27162473

43. Edwards BJ, Raisch DW, Saraykar SS, Sun M, Hammel JA, Tran HT, et al. Hepatotoxicity with Vismodegib: an MD Anderson Cancer Center and Research on Adverse Drug Events and Reports Project. Drugs R D [Internet]. 2017 [cited 2017 Oct 2];17(1):211-8. Available from: https://www .ncbi.nlm.nih.gov/pmc/articles/pmid/28063021/

44. Bello Rivero I. A synergistic immunotherapy for skin cancer [Internet]. Bristol: Scientia Global; 2016 [cited 2017 Oct 2]. 3 p. Available from: http://www.scientiapublications.com/wp-content/ uploads/2016/08/Iraldo-Bello-Rivero.pdf

\section{THE AUTHORS}

Meilyn Fernández-Martori (Corresponding author: fmeilyn.mtz@infomed.sld.cu),dermatologist with a master's degree in infectious diseases. Assistant professor and adjunct researcher, Carlos J. Finlay University Polyclinic, Colón, Cuba.

Iraldo Bello-Rivero, chemist with a master's degree in chemical sciences and doctorate in biological sciences. Senior researcher, Clinical Trials Division, Genetic Engineering and Biotechnology Center (CIGB), Havana, Cuba.

Yaquelin Duncan-Roberts, physician specializing in laboratory medicine, with a master's degree in contemporary biotechnology. Adjunct researcher, Clinical Trials Division, CIGB, Havana, Cuba.

Submitted: January 18, 2017

Approved for publication: December 18, 2017

Disclosures: IBR and YDR are employees of CIGB, which developed HeberPAG, marketed as Heberferon. 